\title{
Physicochemical characteristics, microbiological safety and sensory acceptability of coconut dregs during fermentation using Rhizopus oligosporus
}

\author{
${ }^{1}$ Rosni, N.K., ${ }^{1,2}$ Sanny, M., ${ }^{1}$ Bahranor, N.S.A. and ${ }^{1,3^{*}}$ Rukayadi, Y. \\ ${ }^{1}$ Department of Food Science, Faculty of Food Science and Technology, Universiti Putra Malaysia, 43400 \\ UPM Serdang, Selangor Darul Ehsan, Malaysia \\ ${ }^{2}$ Laboratory of Food Safety and Food Integrity (FOSFI), Institute of Tropical Agriculture and Food \\ Security, Universiti Putra Malaysia, 43400 UPM Serdang, Selangor Darul Ehsan, Malaysia \\ ${ }^{3}$ Laboratory of Natural Products, Institute of Bioscience, Universiti Putra Malaysia, 43400 UPM Serdang, \\ Selangor Darul Ehsan, Malaysia
}

\begin{abstract}
Article history:
Received: 15 January 2020

Received in revised form: 9

March 2020

Accepted: 11 March 2020

Available Online: 29 April 2020
\end{abstract}

\section{Keywords:}

Fermented coconut dregs, Microbiological quality,

Physicochemical

characteristics,

Rhizopus oligosporus,

Sensory acceptability

DOI:

https://doi.org/10.26656/fr.2017.4(5).027

\begin{abstract}
The aims of this study were to determine the changes in physicochemical characteristics, microbiological safety and sensory acceptability of coconut dregs during fermentation using Rhizopus oligosporus. Fermentation of coconut dregs was done using Rhizopus oligosporus as a starter culture for three days (fresh coconut dregs was used as control). The control sample is fresh dregs without any process while other samples will through fermentation. The physicochemical analyses included internal temperature, $\mathrm{pH}$, total soluble solids (TSS), water activity $\left(\mathrm{a}_{\mathrm{w}}\right)$, colour, proximate analysis and texture profile. Microbiological analyses included total plate count (TPC), Escherichia coli, Salmonella spp., Pseudomonas aeruginosa, Bacillus cereus, Staphylococcus aureus and LAB. Sensory acceptability was also carried out. The results showed that internal temperatures and TSS were increased and the $\mathrm{pH}$ decreased throughout the fermentation. The $\mathrm{a}_{\mathrm{w}}$ showed no changes. The colour of fermented coconut dregs had a higher percentage in lightness compared to yellowness and redness which showed that the colour of fermented dregs still maintains the white colour. A gradual increased in hardness, springiness, cohesiveness, chewiness and resilience was observed. Moisture content, crude fat and protein increased while ash and crude fibre decreased but no changes in carbohydrate throughout the fermentation. The results for microbial count showed the reducing number of $S$. aureus and B. cereus while increasing number of TPC and LAB. Interestingly, $E$. coli, Salmonella spp. and P. aeruginosa was not detected in fermented and non-fermented coconut dregs. The non-fermented coconut dregs were preferred more by the panellists as it obtained the highest score in term of colour, odour, texture and overall acceptability on sensory attributes evaluation.
\end{abstract}

\section{Introduction}

Coconut, Cocos mucifera L., is the Cocos genus species, within Aracaceae family, Cocoeae order. Coconut fruit comprises of outer epicarp, a mesocarp, and inner endocarp (Lima et al., 2015; Alshawwa, Elsharif and Abu-Naser, 2019). The coconut has a solid white (kernel) which contains a liquid called coconut water. From the kernel extraction, the coconut oil can be obtained while from shredding and pressed kernel can produce the coconut milk and the shredding kernel without coconut milk is called coconut dregs (Yalegama et al., 2016; Abbasiliasi et al., 2019). Coconut dregs (called hampas kelapa in Malaysia and Indonesia) are easily found in Malaysia and available at low cost or no cost (Hafiza et al., 2011). In addition, this substrate contains high carbohydrate and nutrition content. Some studies find that these coconut dregs have a lot of benefit like high in fibre (Yalegama et al., 2016; Suwitari et al., 2019). According to Syahri and Syahrir (2016), coconut dregs potentially can be good energy source as the animal feed because it has a fairly high protein content that can reach $23 \%$ and the fibre contents in coconut dregs are easily digested by the animal.

Interestingly, in West Java Indonesia, to improve the usage of coconut dregs for human consumption, the coconut dregs have been fermented and called as 
fermented coconut dregs or dage. This food was produced from the fermentation process with inoculation with Rhizopus oligosporus. Fermentation has been a popular technique to preserve the food since ancient time and it is defined as a process where the living organism consumes the nutrients inside the matter and turn it into something desirable (Katz, 2012; Bamforth and Cook, 2019). This fermented food is slightly similar to the tempe bongkrek which is also one of Indonesia's traditional food. However, the tempe bongkrek has the addition of groundnut press cake while fermented coconut dregs did not add it (Deshpande, 2000). $R$. oligosporus uses the coconut dregs as the substrate to obtain the energy and organic material. $R$. oligosporus is one of the moulds that usually used in fermented food products instead of Aspergilus niger and other mixture of yeast, bacteria and fungi. This $R$. oligosporus can survive well in temperature between $25^{\circ} \mathrm{C}$ and $45^{\circ} \mathrm{C}$ (Cantabrana et al., 2015, Sugai-Guérios et al., 2019). The optimum temperature is near $37^{\circ} \mathrm{C}$. Moreover, $R$. oligosporus is also able to grow in 0.88 of water activity $\left(\mathrm{a}_{\mathrm{w}}\right)$ (Pitt, 2002; Sugai-Guérios et al., 2019).

Fermented coconut dregs are usually made manually. Hence, good hygiene practices should be emphasized during fermentation to lower or discards especially from microorganisms that dangerous for health. Previous studies had shown major microorganisms usually involved in this fermented food are Bacilli family like Bacillus subtilis and B. cereus (Steinkraus, 2018). Steinkraus (2018) also stated that tempe bongkrek, which is similar to fermented coconut dregs, has been reported to be contaminated by Pseudomonas species such as Pseudomonas aeruginosa and $P$. cocovenenans. These outbreaks have occurred every year and the government of Indonesia has restricted its production. However, because the food has a delicious flavour and a very low price, the food is continued to be produced. Fermented coconut dregs it not common fermented food, but well known as Indonesia cuisines other than tempeh and oncom which also food from the fermentation process. Based on previous studies, it is proved that fermentation process able to improve the nutrient content while increase digestibility of the food (Hasan et al., 2014; Ray and Didier, 2014; Tamang, 2016).

The intention of this study was to determine the physicochemical characteristics, microbiological safety and sensory acceptability of fermented coconut dregs during fermentation using $R$. oligosporus. The clean coconut dregs that inoculated by $R$. oligosporus were wrapped by banana leaf and left in room temperature for three days. During fermentation, the samples from coconut dregs with $R$. oligosporus were taken on day 0 , 1, 2 and 3 for further analyses. Physicochemical analyses on the following parameters: temperature, $\mathrm{pH}$ value, total soluble solids (TSS), $\mathrm{a}_{\mathrm{w}}$, colour determination, texture profile and chemical analysis (proximate), were conducted. Spread plating method was used to assess the number of microorganism and hedonic scale was used for sensory acceptability analysis.

\section{Materials and methods}

2.1 Coconut dregs fermentation using Rhizopus oligosporus sample

Fresh coconut dregs were obtained from the wet market, Seri Serdang, Selangor, Malaysia and $R$. oligosporus was obtained from Laboratory of Natural Products, Institute of Bioscience (IBS), Universiti Putra Malaysia.

\subsection{Preparation of coconut dregs fermentation using Rhizopus oligosporus}

The coconut dregs fermentation using $R$. oligosporus was prepared manually at Processing Laboratory, Faculty of Food Science and Technology, UPM. Firstly, the coconut dregs were filtered and separated using a filter to remove any impurities. Then, they were washed three times using clean water and steamed for 30 mins. Further, the coconut dregs were dried and cool at room temperature for an hour and mixed well with the ratio of 70:1 which is 1 tsp of $R$. oligosporus into $1 \mathrm{~kg}$ of coconut dregs. Approximately $100 \mathrm{~g}$ of mixed coconut dregs with $R$. oligosporus were weighing and wrapped in banana leaf. The samples were kept in a container and left for 3 days at room temperature for the fermentation process. These samples from different days of fermentation were placed in sterile plastic bags which were properly labelled and dated. Non-fermented coconut dregs were used as control. The non-fermented sample and fermented samples (stored from day 0, day 1, day 2 and day 3) were then brought to the laboratory immediately and analyzed.

\subsubsection{Physicochemical analysis}

The internal temperature of the sample was determined with an infrared thermometer (SCOUT1 INF155) at the geometric centre of each sample from different fermentation day. The $\mathrm{pH}$ value of each sample from different processing steps was determined by $\mathrm{pH}$ meter (3505 Jenway, Staffordshire, United Kingdom). The samples were blended with distilled water at a ratio of 1:5 (w/v) before the determination of $\mathrm{pH}$ (Wongwiwat and Wattanachant, 2015). Total soluble solid ( ${ }^{\circ}$ Brix value) of each sample from fermentation day were determined by using hand refractometer (Model N-300E, ATAGO CO., LTD, USA) of $0 \sim 10$ scale. The samples were diluted with water with dilution factor of 10 . The 
calibration was done with distilled water before testing the samples material. ${ }^{\circ}$ Brix value was calculated using Equation (1) as follows:

Total soluble solid ( ${ }^{\circ}$ Brix) $=$ Reading value $\left({ }^{\circ}\right.$ Brix $) \times$ dilution factor

$a_{w}$ of each sample from fermentation day was measured using water activity meter (Aqualab model series 3TE, Decagon, USA). Samples were cut smaller in order to fill the surface of the cups, and the water activity of the sample was measured at $25 \pm 0.1^{\circ} \mathrm{C}$. The calibration was done at ambient temperature $25 \pm 0.1^{\circ} \mathrm{C}$ with distilled water. Colour determination of each sample from the different days were expressed as $L^{*}, a^{*}$ and $b^{*}$ by Chroma meter (CR-410 Konica Minolta, Japan). Lightness $\left(L^{*}\right)$, red/greenness $\left(a^{*}\right)$ and yellow/blueness $\left(b^{*}\right)$ were determined. For texture analysis, ten replicates from each sample $(2.5 \mathrm{~cm} \times 2.5 \mathrm{~cm} \times 2.5 \mathrm{~cm})$ were evaluated on texture profile using TA-XT2 texture analyser (Stable Microsystem System LTD, United Kingdom) aided with software "Texture Expert". The texture profile analysis (TPA) was performed using P10 (10 mm Dia Cylinder Delrin), pre speed $2.0 \mathrm{~m} / \mathrm{s}$, test speed $1.0 \mathrm{~mm} / \mathrm{s}$, post speed $5.0 \mathrm{~mm} / \mathrm{s}$, strain $50 \%$, trigger force $5.0 \mathrm{~g}$, distance $10.0 \mathrm{~cm}$ and twice puncture. The texture parameters recorded were hardness, springiness, cohesiveness, chewiness and resilience. The colour and texture of food product usually influences the perception of the consumer in acceptability, quality and purchasing decision (Sun et al., 2016).

\subsubsection{Proximate analysis}

The nutritional parameters including the moisture, ash, fats, fibre, protein, carbohydrate and also energy value were determined using the standard official method of Association of Official Analytical Chemists (AOAC, 2012). The moisture content was determined by drying $3 \mathrm{~g}$ of sample in a hot air oven at $105^{\circ} \mathrm{C}$ until a constant weight was obtained and the loss of weight was used for calculation according to AOAC method 952.45 (AOAC, 2012). The ash content was attained by incinerating all organic matter of $3 \mathrm{~g}$ samples at $550^{\circ} \mathrm{C}$ in a muffle furnace for at least $7 \mathrm{hrs}$ until it turns white without any black particles. The crucibles that contain ash was cooled in desiccators and weighed according to AOAC method 945.46 (AOAC, 2012). Crude fats content was determined using the Soxhlet apparatus which used petroleum ether as the solvent according to AOAC method 945.16 (AOAC, 2012). The determination of crude proteins in terms of nitrogen content was done by Micro Kjeldahl method. The nitrogen value was converted to protein content by multiplying by a factor of 6.25 according to AOAC method 981.10 (AOAC, 2012). The weight of crude fibre was calculated by the differences between the weight of dried sample residue to the weight of ash after the digestion of a known weight sample with $1.25 \% \mathrm{H}_{2} \mathrm{SO}_{4}$ and $1.25 \% \mathrm{NaOH}$ solutions under specific conditions according to the AOAC method 926.09 (AOAC, 2012). Lastly, the carbohydrate content was calculated by 100 by subtracting the percentage of moisture content, ash content, crude fat, crude protein and fibre. All physicochemical analyses were performed in triplicate.

\subsection{Microbiological analysis}

Microbiological analysis was performed according to the standard official method of the International Commission on Microbiological Specifications for Foods (ICMSF, 1996). A total of $25 \mathrm{~g}$ of samples was placed in a sterile stomacher bag with $225 \mathrm{~mL}$ of $0.1 \%$ peptone water (OXOID, Hamsphire, United Kingdom) and homogenised for $1 \mathrm{~min}$ in stomacher bag. The $10^{-1}$ dilution was used for subsequent serial dilutions. Dilution was continued from $10^{-1}$ to $10^{-3}$. The microbial count was calculated using Equation (2) as follows:

$$
\text { Microbial count }=\frac{\text { Number of colonies X dilution factor }}{\text { Volume of dilution plated }}
$$

Total plate count (TPC) and Staphylococcus aureus were determined using the Plate Count Agar (PCA) and Mannitol Salt Agar (MSA) (OXOID, Hamsphire, United Kingdom), respectively, which were incubated at $37^{\circ} \mathrm{C}$ for 48 hrs. Escherichia coli, Salmonella spp., Pseudomonas aeruginosa, Bacillus cereus and lactic acid bacteria were enumerated using Eosin Methylene Blue (EMB) Agar, Levine (CRITERION, Santa Maria, USA); Xylene Lysine Deoxycholate (XLD) Agar (Difco ${ }^{\mathrm{TM}}$, Becton, Dickinson and Company Sparks, USA); Mueller Hinton Agar (MHA) (OXOID, Hamsphire, United Kingdom); Bacillus cereus Selective Agar (BSA) (Biolife, Milan, Italy) and Man, Rogosa and Sharpe (MRS) Agar (BHIWADI, Rajasthan, India), respectively, which were incubated at $37^{\circ} \mathrm{C}$ for 24 hrs. All the microbiological analyses were done in triplicate for each sample. The logarithm numbers of colony forming unit per grams $\left(\log _{10} \mathrm{CFU} / \mathrm{g}\right)$ of samples were calculated by observing and enumerating the total colonies formed after incubation.

\subsection{Sensory acceptability}

Sensory acceptability was performed for colour, odour, texture and overall acceptability of fermented coconut dregs samples. A group of thirty random panellists was invited to perform the sensory evaluation. The evaluation was performed based on the 9-point hedonic scale for acceptances in term of attributes given. According to Peryam and Pilgrim (1957), the rating for each analysis of samples was given, ranging scale from like extremely to dislike extremely $(9=$ like extremely, 8 
$=$ like very much, $7=$ like moderately, $6=$ like slightly, 5 $=$ neither like nor dislike, $4=$ dislike slightly, $3=$ dislike moderately, 2 = dislike very much, $1=$ dislike extremely). Individual score for each sample was calculated to achieve the total mean for each sample from each fermentation day.

\subsection{Statistical analysis}

MINITAB (Version 17, Minitab Pennsylvania, USA) statistical application software was used to analyse the data for the one-way analysis of variance (ANOVA). Besides, the Tukey's test was used to determine the significance of differences $(\mathrm{P} \leq 0.05)$ between those samples of different fermentation day. The data was analysed and expressed as mean value \pm standard deviation unless otherwise stated.

\section{Results and discussion}

\subsection{Physicochemical characteristics}

The physicochemical analyses including internal temperature, $\mathrm{pH}$, total soluble solid (TSS), water activity $\left(\mathrm{a}_{\mathrm{w}}\right)$, colour determination, texture and proximate analysis were carried out on the non-fermented and fermented samples. Figure 1 shows the results of internal temperature, $\mathrm{pH}$ value TSS and $\mathrm{a}_{\mathrm{w}}$ while Figure 2 shows the color determination $\left(L^{*}, a^{*}\right.$ and $\left.b^{*}\right)$ results. In addition, Table 1 shows the results of texture while Table 2 shows the proximate composition results.

\subsubsection{Internal temperature}

Figure 1A shows that the internal temperature of fermented coconut dregs significantly increased from $26.0^{\circ} \mathrm{C}$ (day 0 ) to $34.1^{\circ} \mathrm{C}$ (day 3 ). The result is consistent with Deshpande (2000) who reported that the temperature of natto increased to $50^{\circ} \mathrm{C}$ from $40^{\circ} \mathrm{C}$ after 18 hours of fermentation. The heat evolution is produced by the metabolism of the bacteria and it is related to the utilization of the carbon and the energy source (LafonLafourcade, 1983; Pumphrey and Julien, 1996). The catabolized carbon sources are providing energy for cell maintenance and all the enthalpy associated with substrate oxidation is released as heat. Fleet and Heard
(1993) also reported that temperature was one of the factors that directly affect the microbial ecology and the biochemical reaction of the yeasts.

\subsection{2 $\mathrm{pH}$ value}

Figure 1B shows that the $\mathrm{pH}$ of fermented coconut dregs was significantly decreased from 5.18 (day 0) to 3.92 (day 3). Muzdalifah et al. (2017) explained that the breakdown of protein by $R$. oligosporus produced ammonia and it is likely that the formation of ammonia decreased the $\mathrm{pH}$ of fermented coconut dregs. $\mathrm{pH}$ is an important parameter to influence the growth of microorganisms in food. The microorganisms have minimum, maximum and optimum of $\mathrm{pH}$ for growth in food products (ICMSF, 2005). Typically, the $\mathrm{pH}$ of fermented food is below pH 4.5 (Steinkraus, 2018). Hayek and Ibrahim (2013) stated that the formation of lactic acid is one of the main factors the decrease of $\mathrm{pH}$ value. Besides, the metabolite reaction of $R$. oligosporus in fermented coconut dregs that produced the carbon dioxide also one of the factors that decreased the $\mathrm{pH}$ value.

\subsubsection{Total soluble solid}

Figure 1C shows that the total soluble solids (TSS) of fermented coconut dregs was not significantly different from 1.70 (day 0) to 2.00 (day 3). Hernández et al. (2016) stated that TSS can be used to quantify the total sugars of the samples. Thus, the result of TSS showed that the total sugar in coconut dregs fermentation was no changes along with the fermentation duration. During the fermentation, the starter culture of $R$. oligosporus will help to degrade the large molecule of sugars to small molecule (Nout and Kiers, 2005) and increased digestibility of the food (Hasan et al., 2014; Ray and Didier, 2014; Tamang, 2016).

\subsubsection{Water activity}

Figure 1D shows that the $\mathrm{a}_{\mathrm{w}}$ of fermented coconut dregs was determined at 0.99 throughout the fermentation process. Liu (2012) stated that the optimum water activity of polygalactorenase and xylanase in

Table 1. Texture analysis of non-fermented and fermented coconut dregs during fermentation

\begin{tabular}{lccccc}
\hline \multirow{2}{*}{ Texture parameter } & \multirow{2}{*}{ Non-fermented } & \multicolumn{4}{c}{ Fermentation duration (day) } \\
\cline { 3 - 6 } & & 0 & 1 & 2 & 3 \\
\hline Hardness (N) & $60.8 \pm 15.6^{\mathrm{c}}$ & $61.2 \pm 37.3^{\mathrm{c}}$ & $376 \pm 33.5^{\mathrm{b}}$ & $783 \pm 114^{\mathrm{a}}$ & $880 \pm 182^{\mathrm{a}}$ \\
Springiness (mm) & $0.59 \pm 0.09^{\mathrm{a}}$ & $0.60 \pm 0.09^{\mathrm{a}}$ & $0.70 \pm 0.26^{\mathrm{a}}$ & $0.85 \pm 0.08^{\mathrm{a}}$ & $0.86 \pm 0.25^{\mathrm{a}}$ \\
Cohesiveness & $0.33 \pm 0.07^{\mathrm{a}}$ & $0.34 \pm 0.07^{\mathrm{a}}$ & $0.38 \pm 0.03^{\mathrm{a}}$ & $0.39 \pm 0.05^{\mathrm{a}}$ & $0.45 \pm 0.08^{\mathrm{a}}$ \\
Chewiness (Nm) & $11.7 \pm 5.63^{\mathrm{c}}$ & $12.6 \pm 9.29^{\mathrm{c}}$ & $124 \pm 50.1^{\mathrm{bc}}$ & $239 \pm 82.8^{\mathrm{ab}}$ & $257 \pm 38.4^{\mathrm{a}}$ \\
Resilience & $0.13 \pm 0.01^{\mathrm{a}}$ & $0.13 \pm 0.02^{\mathrm{a}}$ & $0.14 \pm 0.01^{\mathrm{a}}$ & $0.14 \pm 0.02^{\mathrm{a}}$ & $0.18 \pm 0.04^{\mathrm{a}}$ \\
\hline
\end{tabular}

Values are mean \pm standard deviation of replications $(n=3)$. Values with different superscript small letters within the same rows are significantly different $(\mathrm{P} \leq 0.05)$. 
fermented food is about 0.99 to 1.00 which is occurred simultaneously with the growth of mycelial. Since coconut dregs contain polygalactorenase and xylanase (Deshpande, 2000), $a_{w}$ during fermentation should in range 0.99 to 1.00 to enhance the growth of mycelial of R. oligosporus.
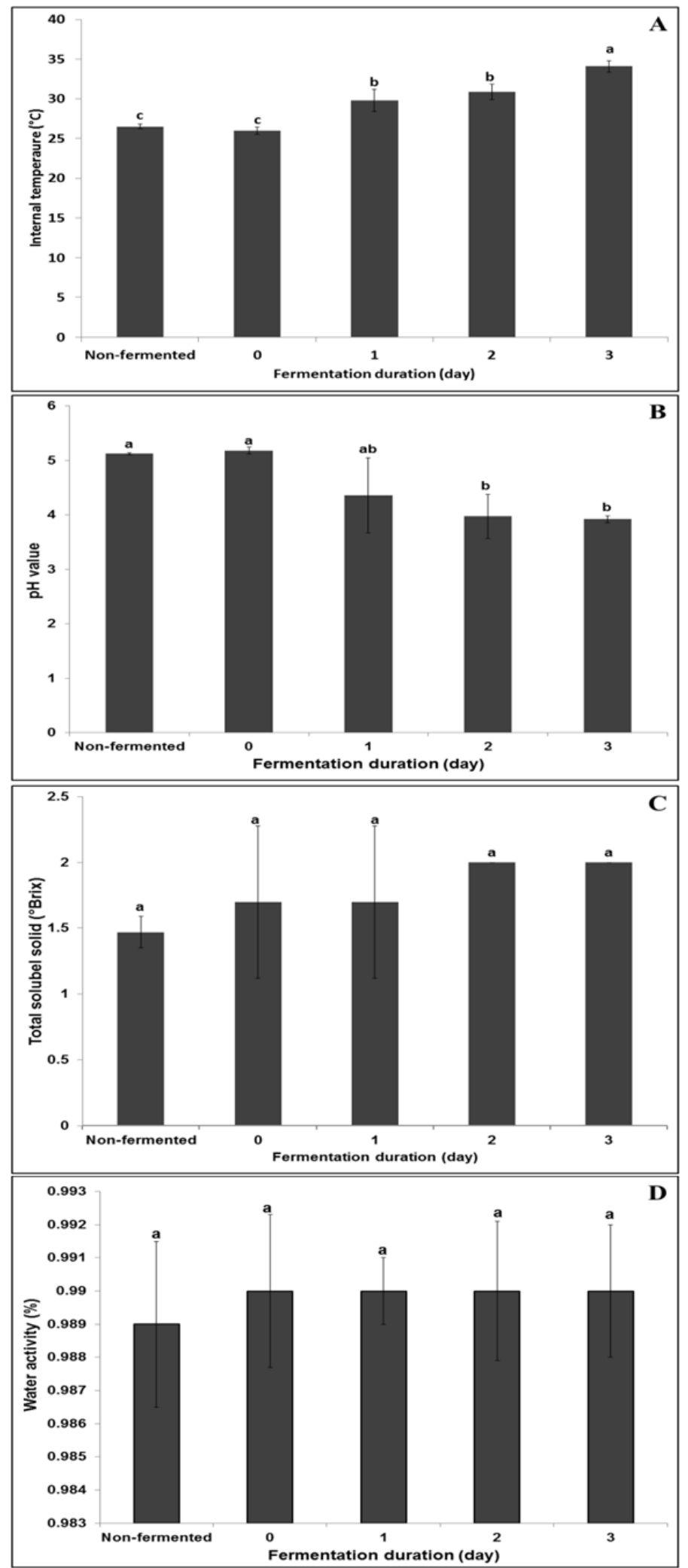

Figure 1. Internal temperature (A), $\mathrm{pH}$ value (B), total soluble solid (C), and water activity (D) of non-fermented and fermented coconut dregs during fermentation.

\subsubsection{Colour determination}

Figure 2 shows the values of lightness and yellowness/blueness of fermented coconut dregs were significantly increased throughout the fermentation. Particularly, coconut dregs of day 3 had the highest lightness (68.5\%) and yellowness (10.65\%) but had the lowest redness $(3.60 \%)$. The finding, however, is in contrast with Muzdalifah et al. (2017), who reported that the lightness of tempeh was decreased during fermentation. Different authors explained that the decreased in the lightness of tempeh was probably due to the increase in the number of $R$. oligosporus that had entered the stationary and death phase Muzdalifah et al. (2017). The colour of the tempeh is yellowish. Therefore, the highest lightness and yellowness of day 3 coconut dregs might be because of dregs itself which is white in colour.

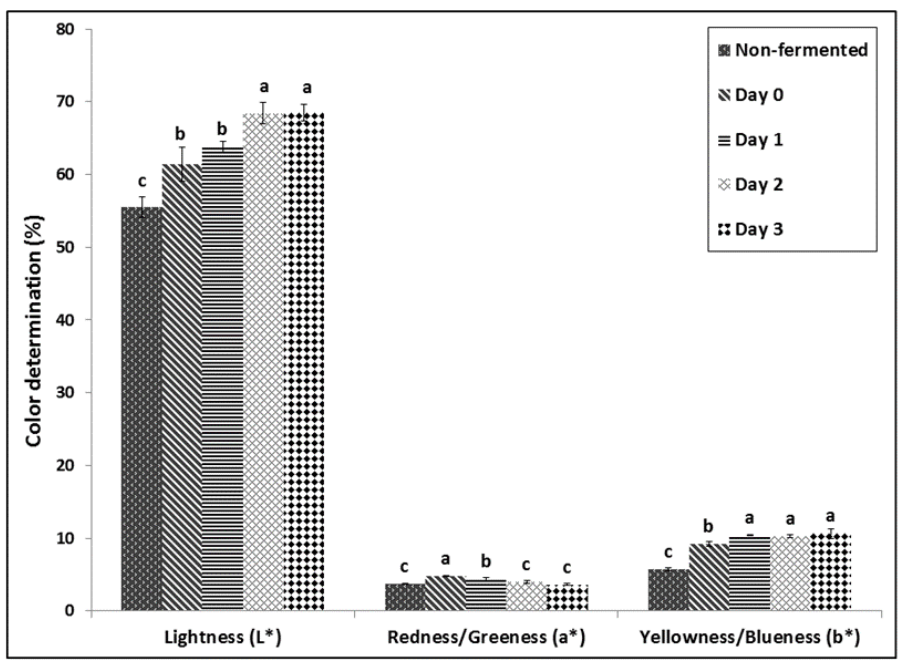

Figure 2. Color determination of non-fermented and fermented coconut dregs during fermentation

\subsubsection{Texture analysis}

Table 1 shows five parameters of texture analysis: hardness, springiness, cohesiveness, chewiness and resilience that were carried out on the non-fermented and fermented coconut dregs. The hardness was significantly increased from $61.2 \mathrm{~N}$ (day 0) to $880 \mathrm{~N}$ (day 3). Nout and Kiers (2005) stated that the increase of hardness is because of the growth of mycelium fungi that formed the network to strengthen the physical structure of fermented coconut dregs. In the present study, coconut dregs were stored at room temperature to ferment dregs and this temperature is suitable for the $R$. oligosporus to grow and to produce mycelium network. Furthermore, Nout and Kiers (2005) stated that the incubation of 1 to 2 day at the ambient temperature of $23-30^{\circ} \mathrm{C}$ is enough to allow the germination of spore and growth of mycelium.

No significant different in springiness, cohesiveness and resilience of non-fermented and fermented coconut dregs throughout the fermentation process. The 
chewiness of fermented coconut dregs, however, significantly increased from $12.6 \mathrm{Nm}$ (day 0 ) to $258 \mathrm{Nm}$ (day 3). Zhu and Sambath (2012) stated that the fermented coconut dregs have a solid shape and soft properties that make fermentation process does not allow the crust formation and increase in chewiness of the sample because crusts do not form during the mycelia growth. In addition, if the crust formation occurs, it will lead to fracturability of the sample and decrease the tender or chewiness of fermented coconut dregs.

\subsubsection{Proximate analysis}

The proximate analyses included determination of moisture content; ash content, crude protein, crude fat, crude fibre and determination of carbohydrate were carried out on the non-fermented sample and fermented samples. Table 2 shows that the moisture content was significantly increased from $74.9 \%$ (day 1) to $78.2 \%$ (day 3). Shurtleff and Aoyagi (2013) discussed that metabolite activity by $R$. oligosporus give off water and have an absolute increase in water amount during fermentation. Hence, moisture content increased as increased in metabolite reaction.

Ash is the inorganic residue remains after burn and represent the total mineral content in foods (Nielsen, 2010). During the fermentation process, the ash content of fermented coconut dregs was significantly decreased from $0.68 \%$ (day 0 ) to $0.28 \%$ (day 3 ). The previous researcher has been reported that the longer the fermentation process, the ash content toward the sample "Gowe", traditional food made by sorghum, millet or maize) will be decreased (Laetitia et al., 2005). The decreased of ash content might be because of the soluble mineral compound was leaching from coconut dregs into water (Igbabul et al., 2014). Jackson et al. (2012) stated that the mineral bioavailability and content are affected by processes such as fermentation process.

Table 2 also shows that the crude protein content was significantly increased from $0.73 \%$ (day 0 ) to $0.98 \%$ (day 3). The result was consistent with previous studies by Olude et al. (2016) which stated that the crude protein increased from $18.0 \%$ to $24.4 \%$ for fermentation of sesame seeds. During the protein digestibility, amino acid and ammonia are released due to high proteolytic activity of Rhizopus sp. which resulting in a high amount of crude protein content in fermented coconut dregs (Deshpande, 2000).

There were no significant differences in percentages of crude fat among day 1, day 2 and day 3 of fermented coconut dregs, except for non-fermented dregs and fermented coconut dregs of day 0 . The result was consistent with Surono (2016) which stated that the total fat was relatively constant throughout the fermentation of tempeh. The starter culture, $R$. oligosporus has a high lipolytic activity which degrades the natural lipid present in coconut dregs such as lauric acid, oleic acid and linoleic acid (Deshpande, 2000). R. oligosporus are actively hydrolysed the triglycerides to obtain the free fatty acid depend on types of substrate and condition of fermentation (Owens, 2014). Only 40\% of fatty acid which is linoleic acid had been utilized by $R$. oligosporus to be used (Surono, 2016).

There was significantly decreased in crude fibre from $6.10 \%$ (day 0 ) to $3.42 \%$ (day 3 ). Crude fibre of fermented coconut dregs was utilized by $R$. oligosporus in order to survive and perform the growth from $\log$ phase to the death phase (Surono, 2016). Percentage of the carbohydrate content of non-fermented dregs and fermented coconut dregs from $13.9 \%$ (day 0 ) have slight differences from $13.8 \%$ (day 3). Carbohydrate content calculated decrease because the natural sugar present in raw coconut dregs has been hydrolysed by the fungus (Oliveira et al., 2010).

\subsection{Microbiological quality}

A total of seven microbiological analyses included total plate count (TPC), Escherichia coli, Salmonella spp., Pseudomonas aeruginosa, Bacillus cereus and Staphylococcus aureus were carried out on the nonfermented and fermented coconut dregs. Figure 3 shows that TPC was increased from $4.76 \log _{10} \mathrm{CFU} / \mathrm{g}$ (day 0 ) to $5.44 \log _{10} \mathrm{CFU} / \mathrm{g}$ (day 3). Total plate count cannot

Table 2. Proximate analysis for non-fermented and fermented coconut dregs during fermentation

\begin{tabular}{lccccc}
\hline \multirow{2}{*}{$\begin{array}{c}\text { Proximate analysis } \\
(\%)\end{array}$} & Non-fermented & \multicolumn{4}{c}{ Fermentation duration (day) } \\
\cline { 3 - 6 } & & 0 & 1 & 2 & 3 \\
\hline Moisture & $76.5 \pm 0.42^{\mathrm{bc}}$ & $76.3 \pm 0.34^{\mathrm{c}}$ & $74.9 \pm 0.40^{\mathrm{d}}$ & $77.4 \pm 0.12^{\mathrm{ab}}$ & $78.2 \pm 0.40^{\mathrm{a}}$ \\
Ash & $0.69 \pm 0.04^{\mathrm{a}}$ & $0.68 \pm 0.02^{\mathrm{a}}$ & $0.42 \pm 0.02^{\mathrm{b}}$ & $0.29 \pm 0.01^{\mathrm{c}}$ & $0.28 \pm 0.01^{\mathrm{c}}$ \\
Crude protein & $0.70 \pm 0.28^{\mathrm{a}}$ & $0.73 \pm 0.00^{\mathrm{a}}$ & $0.74 \pm 0.00^{\mathrm{a}}$ & $0.98 \pm 0.001^{\mathrm{b}}$ & $0.98 \pm 0.01^{\mathrm{b}}$ \\
Crude fat & $2.18 \pm 0.10^{\mathrm{b}}$ & $2.28 \pm 0.06^{\mathrm{b}}$ & $3.26 \pm 0.06^{\mathrm{a}}$ & $3.29 \pm 0.39^{\mathrm{a}}$ & $3.33 \pm 0.21^{\mathrm{a}}$ \\
Crude fibre & $6.32 \pm 0.44^{\mathrm{a}}$ & $6.10 \pm 0.18^{\mathrm{ab}}$ & $5.94 \pm 0.02^{\mathrm{ab}}$ & $5.54 \pm 0.39^{\mathrm{b}}$ & $3.42 \pm 0.10^{\mathrm{c}}$ \\
Carbohydrate & $13.6 \pm 0.31^{\mathrm{b}}$ & $13.9 \pm 0.51^{\mathrm{ab}}$ & $14.8 \pm 0.47^{\mathrm{a}}$ & $12.9 \pm 0.55^{\mathrm{b}}$ & $13.8 \pm 0.30^{\mathrm{ab}}$ \\
\hline
\end{tabular}

Values are mean \pm standard deviation of replications $(n=3)$. Values with different superscript small letters within the same rows are significantly different $(\mathrm{P} \leq 0.05)$. 
differentiate between the natural background of spoilage microorganisms and pathogenic microorganisms (Centre for Food Safety, 2014). Therefore, the increasing number of total plate count might be because of the increasing number of the lactic acid bacteria which is the bacteria that important in the fermentation process (Quinto et al., 2014). The increasing number of total plate count also might be due to the starter culture of fermented coconut dregs which is $R$. oligosporus. Surono (2016) also stated that microbial load can be more than $10^{7} \mathrm{CFU} / \mathrm{g}(>7$ $\log _{10} \mathrm{CFU} / \mathrm{g}$ ) of aerobic plate counts which is conquered by lactic acid bacteria.

Interestingly, there were no E. coli, Salmonella spp. and $P$. aeruginosa detected in fermented and nonfermented coconut dregs. E. coli present in the environment usually cause by faecal contamination (Welch, 2006) while $P$. aeruginosa found widely in the environment, such as in soil, water, and plants. Thus, it shows that the process of coconut dregs fermentation is cleaned and hygienic from contaminated by those bacteria.

Figure 3 also shows $B$. cereus was decreased from $3.27 \log _{10} \mathrm{CFU} / \mathrm{g}$ (day 0) to $2.82 \log _{10} \mathrm{CFU} / \mathrm{g}$ (day 3 ). Byaruhanga et al. (1999) stated that B. cereus was reduced to smaller numbers in $24 \mathrm{hrs}$ in lactic fermenting products such as fermented coconut dregs. Besides, the increase of lactic acid bacteria also affected $B$. cereus because of the increasing level of lactic acid and decreasing $\mathrm{pH}$ value (Ashenafi and Busse, 1991). Svanberg et al. (1992) also reported similar inhibition of $B$. cereus in acidified gruel. Hence, the decrease in the viable $B$. cereus as shown in Figure 3 was possibly due to the low $\mathrm{pH}$ and high acidity resulting from the presence of lactic acid.

Figure 3 also shows $S$. aureus was increased from $5.01 \log _{10} \mathrm{CFU} / \mathrm{g}$ (day 0) to $5.39 \log _{10} \mathrm{CFU} / \mathrm{g}$ (day 2) and decreased to $4.36 \log _{10} \mathrm{CFU} / \mathrm{g}$ (day 3). Surono (2016) reported the presence of $S$. aureus during tempeh fermentation. The presence of this bacteria and others and also yeasts on tempeh production are provide developing of flavour and modification of substrate in the safety of the product (Nout and Kiers, 2005).

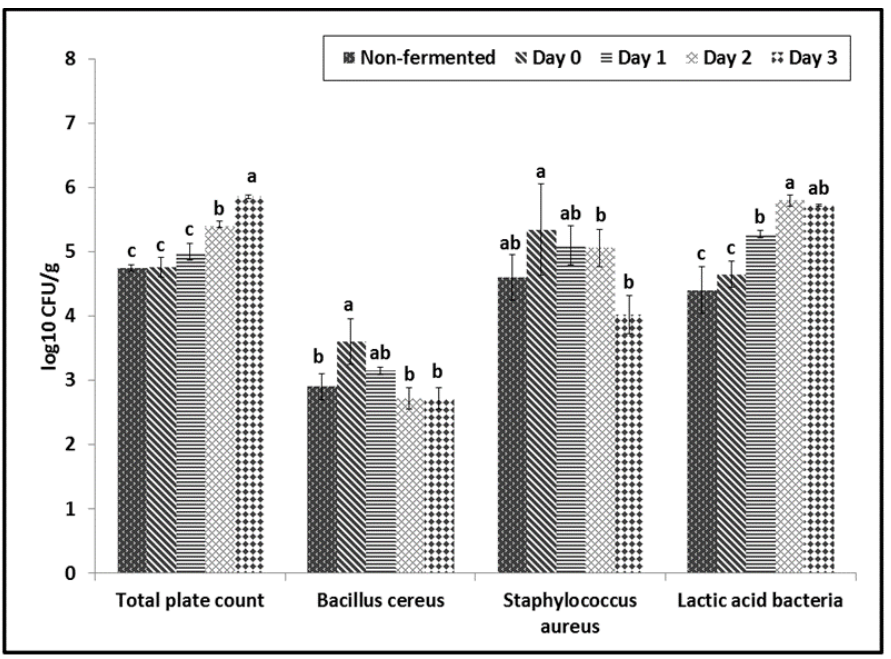

Figure 3. Microbial counts that present on non-fermented and fermented coconut dregs during fermentation.

Figure 3 shows lactic acid bacteria was increased from $4.57 \log _{10} \mathrm{CFU} / \mathrm{g}$ (day 0) to $5.86 \log _{10} \mathrm{CFU} / \mathrm{g}$ (day 1) and start to slightly decrease to $5.63 \log _{10} \mathrm{CFU} / \mathrm{g}$ (day 3 ). The increased and later decreased is because of the cycle life of the lactic acid bacteria itself. Zwietering et al. (1990) mentioned that in day 0 of fermentation, the lactic acid beginning to grow that is called the lag phase. Later, the count of lactic acid bacteria increased because of the bacteria grows rapidly or it called exponential phase. Then, the bacteria started to maintain (stationary phase) and decrease (death phase). Lactic acid bacteria play an important role in the fermentation process by producing lactic acid (Hayek and Ibrahim, 2013). The increasing of these bacteria is good for the fermentation process.

\subsection{Sensory acceptability}

Table 3 shows the results of the sensory acceptability of colour, odour, texture and overall acceptability on the non-fermented and fermented coconut dregs. All the colour, odour, texture and overall acceptability of fermented coconut dregs from day 0 , day 1 , day 2 and day 3 were gradually decreased with increasing fermentation day. In general, fermented foods will produce a specific smell which only can be acceptable by old decent. The odour of the fermented coconut dregs gives the strong odour of ammonia, a product from protein breakdown (Hui and Evranuz, 2015). Ammonia

Table 3. Sensory acceptability of non-fermented and fermented coconut dregs during fermentation

\begin{tabular}{lccccc}
\hline \multirow{2}{*}{ Proximate analysis (\%) } & \multirow{2}{*}{ Non-fermented } & \multicolumn{4}{c}{ Fermentation duration (day) } \\
\cline { 3 - 6 } & & 0 & 1 & 2 & 3 \\
\hline Colour & $7.33 \pm 1.45^{\mathrm{a}}$ & $6.87 \pm 1.91^{\mathrm{a}}$ & $4.77 \pm 1.98^{\mathrm{b}}$ & $5.03 \pm 2.14^{\mathrm{b}}$ & $4.77 \pm 2.08^{\mathrm{b}}$ \\
Odour & $6.67 \pm 1.97^{\mathrm{a}}$ & $6.57 \pm 2.32^{\mathrm{a}}$ & $2.90 \pm 2.11^{\mathrm{b}}$ & $3.43 \pm 2.40^{\mathrm{b}}$ & $2.83 \pm 1.95^{\mathrm{b}}$ \\
Texture & $6.77 \pm 1.63^{\mathrm{a}}$ & $6.33 \pm 1.99^{\mathrm{a}}$ & $4.20 \pm 1.96^{\mathrm{b}}$ & $4.67 \pm 2.09^{\mathrm{b}}$ & $4.23 \pm 2.06^{\mathrm{b}}$ \\
Overall Acceptability & $7.00 \pm 1.53^{\mathrm{a}}$ & $6.47 \pm 1.83^{\mathrm{a}}$ & $4.10 \pm 1.90^{\mathrm{b}}$ & $4.33 \pm 2.26^{\mathrm{b}}$ & $4.27 \pm 1.96^{\mathrm{b}}$ \\
\hline
\end{tabular}

Values are mean \pm standard deviation of replications $(n=3)$. Values with different superscript small letters within the same rows are significantly different $(\mathrm{P} \leq 0.05)$. 
smell has a strong pungent smell that influences the acceptability of the panellists. Moreover, a fermented coconut dreg is not familiar with Malaysian people but it acceptable among Indonesian.

\section{Conclusion}

In conclusion, the presence of $R$. oligosporus helps in the fermentation process. The growth of mycelia affects the lightness $\left(L^{*}\right)$ and yellowness $\left(b^{*}\right)$ of fermented coconut dregs along fermentation was increased and decreased in redness $\left(a^{*}\right)$. It also gives affects to the hardness, springiness, cohesiveness, chewiness and resilience of texture analysis for fermented coconut dregs was increased from day 0 to day 3. Furthermore, the final product of coconut dregs fermentation using $R$. oligosporus, fermented coconut dregs or dage is safe as it has a low level of microbial count and good quality as it rich of lactic acid bacteria (LAB). Besides, the increase of protein content through the fermentation showed that the fermented coconut dregs can be one of good fermented food as it has a high of protein on it. However, the sensory acceptability of fermented coconut dregs did not acceptable in term of colour, odour, texture and overall acceptability since non -Indonesian is not familiar with fermented coconut food yet. This study was conducted principally for the achievement on the physiochemical characteristics, microbiological safety and quality, and sensory acceptability of fermented coconut dregs during fermentation day. $R$. oligosporus scientifically had proven found dominant in fermentation food and it can be proved that fermentation can change the nutrition and texture of non-fermented dregs. However, there is some limitation to the current study. Recommendations for future research are to study the effect of different starter culture or mixed starter culture on coconut dregs fermentation and the best ways to consume it in term of sensory acceptability. In addition, a study on shelf life test of fermented coconut dregs can also be performed.

\section{Conflict of interest}

The authors declared no conflict interest. The authors alone are responsible for the content of the paper.

\section{Acknowledgments}

This work was supported by Geran Putra IPS to Yaya Rukayadi Project Number GP-IPS/2018/9620200.

\section{References}

Abbasiliasi, S., Tan, J.S., Bello, B., Ibrahim, T.A.T., Tam, Y.J., Ariff, A. and Mustafa, S. (2019). Prebiotic efficacy of coconut kernel cake's soluble crude polysaccharides on growth rates and acidifying property of probiotic lactic acid bacteria in vitro. Biotechnology and Biotechnological Equipment, 33 (1), 1216-1227. https:// doi.org/10.1080/13102818.2019.1649603

Alshawwa, I.A., Elsharif, A.A. and Abu-Naser, S.S. (2019). An expert system for coconut diseases diagnosis. International Journal of Academic Engineering Research (IJAER), 3(4), 8-13.

AOAC (Association Official Analytical Chemists). (2012). Official Methods of Analysis. 19th ed. Washington DC, USA: Association Official Analytical Chemists.

Ashenafi, M. and Busse, M. (1991). Growth of Bacillus cereus in fermenting tempeh made from various beans and its inhibition by Lactobacillus plantarum. Journal of Applied Bacteriology, 70(4), 329-333. https://doi.org/10.1111/j.1365-2672.1991.tb02944.x

Bamforth, C.W. and Cook, D.J. (2019). Food, fermentation, and micro-organisms. United Kingdom: John Wiley and Sons. https:// doi.org/10.1002/9781119557456

Byaruhanga, Y.B., Bester, B.H. and Watson, T.G. (1999). Growth and survival of Bacillus cereus in mageu, a sour maize beverage. World Journal of Microbiology and Biotechnology, 15(3), 329-333. https://doi.org/10.1023/A:1008967117381

Cantabrana, I., Perise, R. and Hernández, I. (2015). Uses of Rhizopus oryzae in the kitchen. International Journal of Gastronomy and Food Science, 2(2), 103111. https://doi.org/10.1016/j.ijgfs.2015.01.001

Centre for Food Safety. (2014). Microbiological Guidelines for Food (For ready-to-eat food in general and specific food items). Queensway, Hong Kong: Food and Environmental Hygiene Department.

Deshpande, S.S. (2000). Fermented grain legumes, seeds and nuts: a global perspective. Vol. 142, Rome, Italy: FAO.

Fleet, G.M. and Heard, G.M. (1993). Yeasts-growth during fermentation. In Fleet, G.H. (Ed.) Wine Microbiology and Biotechnology., p. 27-55. Chur, Switzerland, Harwood Academic Publishers.

Hafiza, S., Ahmad Anas, N.G. and Nor Hidayah, B. (2011). Screening of potential strain for bioprotein production from coconut dregs. In 2011 International Conference on Food Engineering and Biotechnology. Vol. 9, p. 296-299. Singapore: IACSIT Press.

Hasan, M.N., Sultan, M.Z. and Mar-E-Um, M. (2014). Significance of fermented food in nutrition and food science. Journal of Scientific Research, 6(2), 373- 
386. https://doi.org/10.3329/jsr.v6i2.16530

Hayek, S.A. and Ibrahim, S.A. (2013). Current limitations and challenges with lactic acid bacteria: a review. Food and Nutrition Sciences, 4(11), 73-87. https://doi.org/10.4236/fns.2013.411A010

Hernández, F., Noguera-Artiaga, L., Burló, F., Wojdyło, A., Carbonell-Barrachina, Á.A. and Legua, P. (2016). Physico-chemical, nutritional, and volatile composition and sensory profile of Spanish jujube (Ziziphus jujuba Mill.) fruits. Journal of the Science of Food and Agriculture, 96(8), 2682-2691. https:// doi.org/10.1002/jsfa.7386

Hui, Y.H. and Evranuz, E.Ö. (Eds.). (2015). Handbook of vegetable preservation and processing. USA: CRC Press. https://doi.org/10.1201/b19252

ICMSF (International Commission on Microbiological Specifications for Foods). (1996). Microorganisms in food 5: Microbiological specifications of food pathogens. London: Blackie Academic and Professional.

ICMSF (International Commission on Microbiological Specifications for Foods) (2005). Microbial ecology of foods. Volume 2, Factors affecting life and death of microorganisms. Vol. 2, $2^{\text {nd }}$ ed. Orlondo, USA: Academic Press,

Igbabul, B.D., Bello, F.A. and Ani, E.C. (2014). Effect of fermentation on the proximate composition and functional properties of defatted coconut (Cocos nucifera L.) flour. Sky Journal of Food Science, 3(5), 034-040.

Jackson, L.S., Knize, M.G. and Morgan, J.N. (Eds.). (2012). Impact of Processing on Food Safety. Vol. 459. USA: Springer Science and Business Media.

Katz, S.E. (2012). The art of fermentation: an in-depth exploration of essential concepts and processes from around the world. United Kingdom: Chelsea Green Publishing.

Laetitia, M.M., Joseph, H.D., Joseph, D. and Christian, M. (2005). Physical, chemical and microbiological changes during natural fermentation of gowé, a sprouted or non-sprouted sorghum beverage from West-Africa. African Journal of Biotechnology, 4, 487-496.

Lafon-Lafourcade, S. (1983). Wine and brandy. In Reed, G. (Ed.) Biotechnology. Food and feed production with microorganisms. Vol. 5, p. 81-63. Weinheim, Germany: Verlag Chemie.

Liu, K. (2012). Soybeans: chemistry, technology, and utilization. Singapore: Springer.

Lima, E.B.C., Sousa, C.N.S., Meneses, L.N., Ximenes, N.C., Júnior, S., Vasconcelos, G.S., Lima, N.B.C., Patrocinio, M.C.A., Macedo, D. and Vasconcelos,
S.M.M. (2015). Cocos nucifera (L.) (Arecaceae): A phytochemical and pharmacological review. Brazilian Journal of Medical and Biological Research, 48(11), 953-964. https:// doi.org/10.1590/1414-431 x20154773

Muzdalifah, D., Athaillah, Z.A., Nugrahani, W. and Devi, A.F. (2017). Colour and $\mathrm{pH}$ changes of tempe during extended fermentation. AIP Conference Proceedings, 1803(1), 020036. https:// doi.org/10.1063/1.4973163

Nielsen, S.S. (Ed.). (2010). United States government regulations and international standards related to food analysis. In Food Analysis., p.15-33. Boston, USA: Springer. https://doi.org/10.1007/978-1-44191478-1_2

Nout, M.J.R. and Kiers, J.L. (2005). Tempe fermentation, innovation and functionality: update into the third millennium. Journal of Applied Microbiology, 98(4), 789-805. https:// doi.org/10.1111/j.1365-2672.2004.02471.x

Oliveira, M.D.S., Feddern, V., Kupski, L., Cipolatti, E.P., Badiale-Furlong, E. and de Souza-Soares, L.A. (2010). Physico-chemical characterization of fermented rice bran biomass Caracterización fisicoquímica de la biomasa del salvado de arroz fermentado. CyTA-Journal of Food, 8(3), 229-236. https://doi.org/10.1080/19476330903450274

Olude, O., George, F. and Alegbeleye, W. (2016). Utilization of autoclaved and fermented sesame (Sesamum indicum L.) seed meal in diets for Tilaqua natural male tilapia. Animal Nutrition, 2(4), 339 -344. https://doi.org/10.1016/j.aninu.2016.09.001

Owens, J.D. (2014). Indigenous fermented foods of Southeast Asia. USA: CRC Press. https:// doi.org/10.1201/b17835

Peryam, D.R. and Pilgrim, F.J. (1957). Hedonic scale method of measuring food preferences. Food Technology, 11(Suppl.), 9-14.

Pitt, J.I. (2002). Biology and ecology of toxigenic Penicillium species. In DeVries, J.W., Trucksess, M.W. and Jackson, L.S. (Eds.. Mycotoxins and food safety. Advances in Experimental Medicine and Biology., Vol. 504., p. 29-41. Boston, USA: Springer. https://doi.org/10.1007/978-1-4615-06294_4

Pumphrey, B. and Julien, C. (1996). An introduction to fermentation. Fermentation Basics., p. 1-24. United Kingdom: New Brunswick Scientific.

Quinto, E.J., Jiménez, P., Caro, I., Tejero, J., Mateo, J. and Girbés, T. (2014). Probiotic lactic acid bacteria: A review. Food and Nutrition Sciences, 5, 17651775. https://doi.org/10.4236/fns.2014.518190 
Ray, R.C. and Didier, M. (Eds.). (2014). Microorganisms and fermentation of traditional foods. USA: CRC Press. https://doi.org/10.1201/b17307

Shurtleff, W. and Aoyagi, A. (2013). History of tofu and tofu products (965 CE to 2013). USA: Soyinfo Center.

Steinkraus, K.H. (2018). Handbook of Indigenous Fermented Foods, revised and expanded. $2^{\text {nd }}$ ed., $p$. 76-79. Boca Raton, USA; CRC Press. https:// doi.org/10.1201/9780203752821

Sugai-Guérios, M.H., Balmant, W., Krieger, N., Junior, A.F. and Mitchell, D.A. (2019). More random-walk than autotropism: A model-based study on how aerial hyphae of Rhizopus oligosporus grow in solidstate fermentation. Biochemical Engineering Journal, 141, 49-59. https://doi.org/10.1016/ j.bej.2018.08.008

Sun, X., Jin, Q. and Li, X. (2016). Physical quality changes of pre-cooked shrimps during frozen storage. Advances in Engineering Research, 63, 7681. https://doi.org/10.2991/icseee-16.2016.13

Surono, I.S. (2016). Ethnic fermented foods and beverages of Indonesia. In Ethnic Fermented Foods and Alcoholic Beverages of Asia., p. 341-382. New Delhi, India: Springer. https://doi.org/10.1007/97881-322-2800-4_14

Suwitari, N.K.E., Suariani, L., Yudiastari, N.M., Kaca, N. and Tonga, Y. (2019, December). Performance of 0-14 weeks-aged super free-range hens that are fed by fermented coconut pulp flour-contained ration. Journal of Physics: Conference Series, 1402(5), $055027 . \quad$ https://doi.org/10.1088/1742$6596 / 1402 / 5 / 055027$

Svanberg, U., Sjögren, E., Lorri, W., Svennerholm, A.M. and Kaijser, B. (1992). Inhibited growth of common enteropathogenic bacteria in lactic-fermented cereal gruels. World Journal of Microbiology and Biotechnology, 8(6), 601-606. https:// doi.org/10.1007/BF01238797

Syahri, Y.F. and Syahrir, S. (2016). Potency of Dregs Coconut Fermentation (Cocos Nucifera) as an Alternative Feed for Fish and Poultry 'Pa-bio'. Agrotech Journal, 1, 45-49. https://doi.org/10.31327/ atj.v1i1.198

Tamang, J.P. (Ed.). (2016). Ethnic fermented foods and alcoholic beverages of Asia., p. 4-5. Delhi, India: Springer. https://doi.org/10.1007/978-81-322-2800-4

Welch, R.A. (2006). The Genus Escherichia. In Dworking, M., Falkow, S., Rosenberg, E., Schelifer, K.H. and Stackebrandt, E. (Eds.). The Prokaryotes., p. 60-71. New York, USA: Springer. https:// doi.org/10.1007/0-387-30746-X_3
Wongwiwat, P. and Wattanachant, S. (2015). Quality changes of chicken meat jerky with different sweeteners during storage. Journal of Food Science and Technology, 52(12), 8329-8335. https:// doi.org/10.1007/s13197-015-1884-2

Yalegama, L.L.W.C., Sivakanesan, R. and Karunarathna, D.N. (2016). Effect of coconut kernel residues on serum lipid concentrations of rats. Procedia Food Science, 6, 186-189. https://doi.org/10.1016/ j.profoo.2016.02.045

Zhu, E. and Sambath, S. (Eds.). (2012). Information Technology and Agricultural Engineering., p. 134. USA: Springer Science and Business Media. https:// doi.org/10.1007/978-3-642-27537-1

Zwietering, M.H., Jongenburger, I., Rombouts, F.M. and Van't Riet, K. (1990). Modelling of the bacterial growth curve. Applied Environment and Microbiology, 56(6), 1875-1881. https:// doi.org/10.1128/AEM.56.6.1875-1881.1990 